

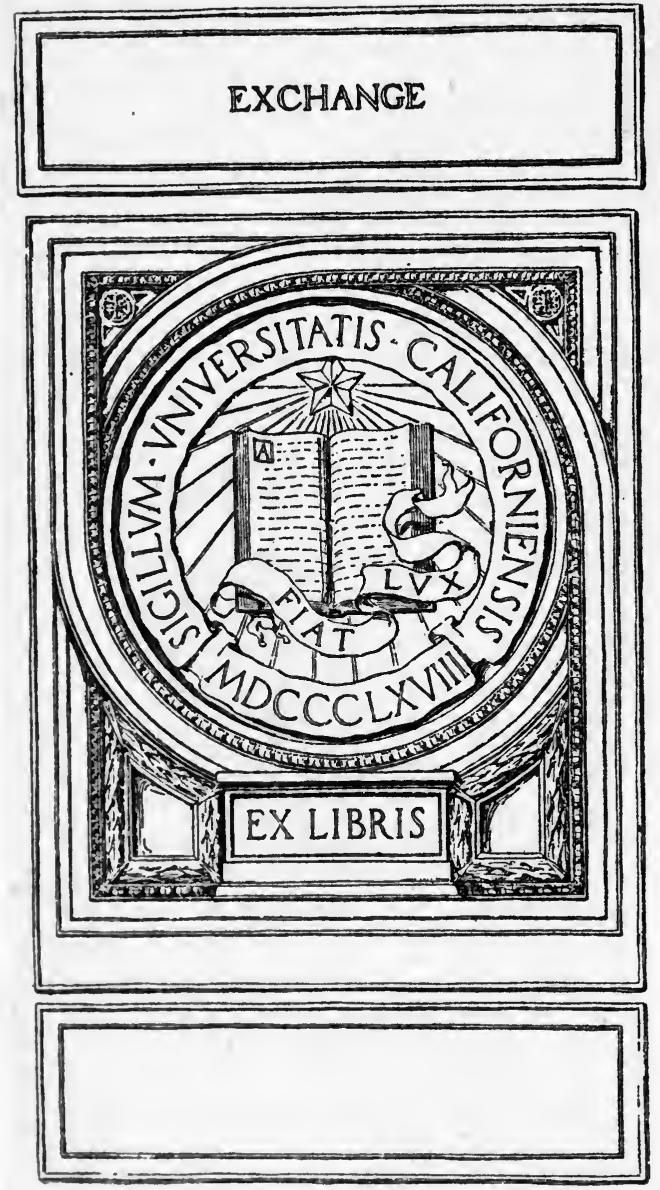



Digitized by the Internet Archive in 2007 with funding from Microsoft Corporation 


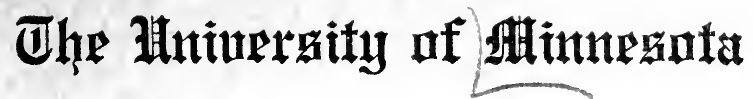

CURRENT PROBLEMS

NUMBER $S$

\section{BULLETIN FOR TEACHERS OF GERMAN}

\section{BY}

CARL SCHLENKER, B.A.

Professor of German in the University of Minnesota

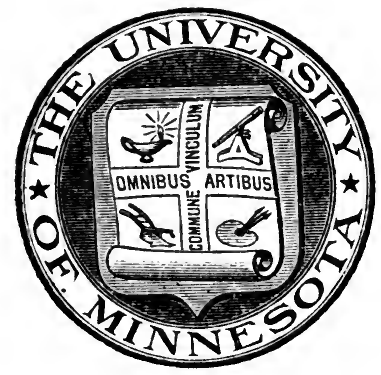

MINNEAPOLIS

Bulletin of the University of Minnesota

August 1916

Price 25 Cents 


\section{RESEARCH PUBLICATIONS \\ OF THE \\ UNIVERSITY OF MINNESOTA}

These publications contain the results of research work from various departments of the University and are offered for exchange with universities, scientific societies, and other institutions. Papers will be published as separate monographs numbered in several series. There is no stated interval of publication. Application for any of these publications should be made to the University Librarian.

\section{STUDIES IN THE SOCIAL SCIENCES}

1. Thompson and Warber, A Social and Economic Survey of a Rural Township in Southern Minnesota. April, 1913. $\$ 0.50$.

2. Matthias Nornberg Orfield, Federal Land Grants to the States, with Special Reference to Minnesota. March, 1915. \$1.00.

3. Enward Van Dyke Robinson, Early Economic Conditions and the Development of Agriculture in Minnesota. March, 1915. $\$ 1.50$

4. L. D. H. Weln and Others, Studies in the Marketing of Farm Products. March, 1915. $\$ 0.50$.

5. Ben Palmer, Swamp Land Drainage, with Special Reference to Minnesota. March, 1915. \$0.50.

6. Albert Ernest Jeniss, Indian-White Amalgamation: An Anthropometric Study. March, 1916. \$0.50.

7. Cepruas Daniel Allin, A History of the Tariff Relations of the Australian Colonies. In press.

\section{STUDIES IN THE PHYSICAL SCIENCES AND MATHEMATICS}

1. Frankforter and Frary, Equilibria in Systems containing Alcohol, Salts, and Water. December, 1912. $\$ 0.50$.

2. Frankforter and Kritchevsky, A New Phase of Catalysis. February, 1914. $\$ 0.50$.

\section{STUDIES IN ENGINEERING}

1. George Arfred Maney, Secondary Stresses and Other Problems in Rigid Frames: A New Method of Solution. March, 1915. \$0.25.

2. Charles Franklin Shoop, An Investigation of the Concrete RoadMaking Properties of Minnesota Stone and Gravel. March, 1915. \$0.25.

3. Franklin R. McMrllan, Shrinkage and Time Effects in Reinforced Concrete. March, 1915. \$0.25.

\section{STUDIES IN THE BIOLOGICAL SCIENCES}

1. Herbert G. Lampson, A Study on the Spread of Tuberculosis in Families. December, 1913. $\$ 0.50$.

(Continued inside back cover) 


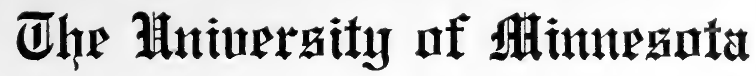

CURRENT PROBLEMS

NUMBER 8

\section{BULLETIN FOR TEACHERS OF GERMAN}

\section{BY}

CARL SCHLENKER, B.A.

Professor of German in the University of Minnesota

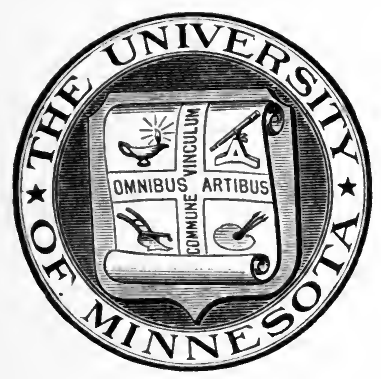

MINNEAPOLIS

Bulletin of the University of Minnesota

August 1916 


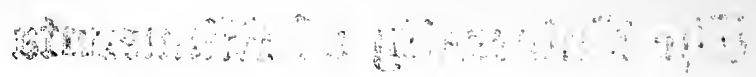

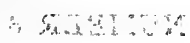

Copyright 1916

The University of Minnesota 


\section{PREFACE}

This is the third of a series of bulletins on the teaching of high-school subjects, prepared under the auspices of the College of Education at the University of Minnesota. These bulletins do not undertake to give detailed treatment of special methods or of many other important matters covered in the special methods courses at the University. They are, however, designed to present a summary of the text-books and materials available to teachers of the various subjects. In every bulletin an effort is made to confine the discussion to those problems which confront the beginning teacher and to supply those aids, suggestions, and materials which should be at her disposal in solving such problems.

The Bulletin for Teachers of Latin was prepared by Professor Joseph B. Pike, and the Bulletin for Teachers of History was prepared by Professor August C. Krey. These and succeeding bulletins may be secured by addressing the Librarian, University of Minnesota, and enclosing the price, 25 cents each.

Lotus D. Coffman

Dean of the College of Education 



\section{CONTENTS}

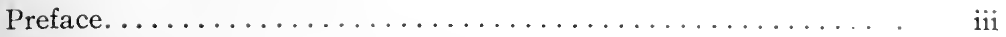

Methods ...................................... 1-8

Choice of method........................... 1

Different methods defined...................... 2

The Grammar-Translation Method................. 2

The Conversation Method...................... 3

The Direct or Reading Method.................... 4

Advantages of the Direct Method................. 5

Disadvantages of the Direct Method............... 6

How to teach by the Direct Method.............. 7

Bibliographical list........................ 7

General............................

Theory and practice..................... 7

The Gouin Method...................... 8

The Direct Method....................... 8

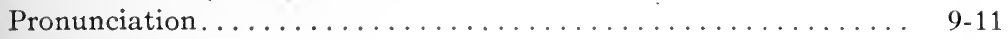

Discussion............................. 9

Bibliographical list......................... 10

Standard German...................... 10

Phonetics............................ 10

How to teach pronunciation................... 10

Charts for teaching sounds.................. 10

Grammar and Composition .................... 12-15

Grammar............................. 12

Composition............................. 13

Bibliographical list........................... 14

Reference grammars for teachers................ 14

Helpful and related books....................... 14

Dictionaries............................. 15

Practice in Speaking. . . . . . . . . . . . . . . . . . . $16-23$

Discussion............................. 16

Some Don'ts for the teacher.................. 17

Illustrative material. . . . . . . . . . . . . . . . . . . 18

Land and Leute........................... 18

General................................. 18

Illustrated, and of historical interest. . . . . . . . . 19

Story and legend ......................... 19

Postcards, photographs, pictures................ 19

Wall pictures, charts, for conversation drill........... 19

Miscellaneous .............................. 20

Maps and charts............................. 20

Geographical maps........................ 20 20

Historical maps........................... 20

Maps for Wilhelm Tell .................... 20

Maps for Jungfrau von Orleans................ 20 


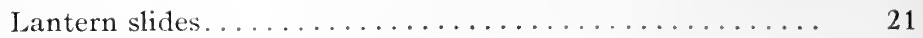

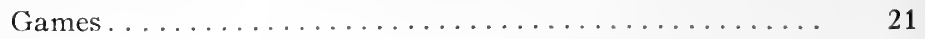

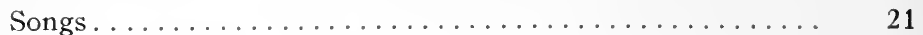

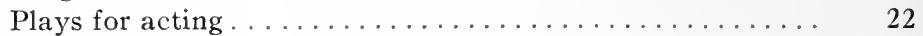

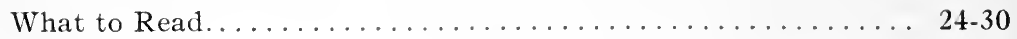

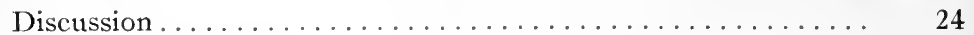

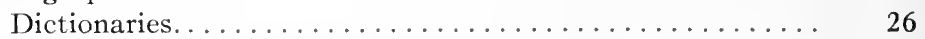

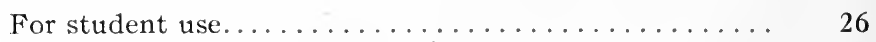

For teachers and the library................ 26

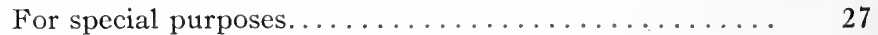

Technical dictionaries.................... 27

Reference books on German literature............. 27

General histories of German literature.......... 27

Histories of the nineteenth century literature....... 28

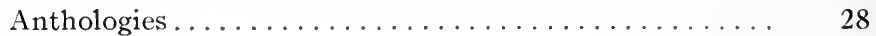

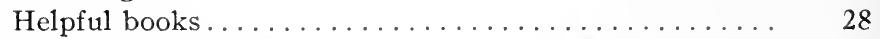

The classic writers ..................... 29

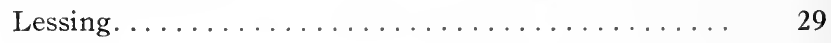

Goethe............................ 29

Schiller. . . . . . . . . . . . . . . . . . . . . . . . . . 29

Reference books for German history............. 30

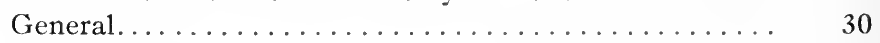

Related books........................ 30

The Self-Improvement of the Teacher................ 31-34

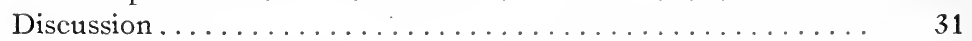

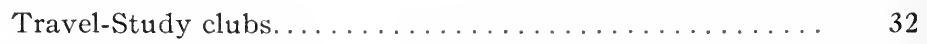

Summer sessions abroad ................... 32

Bibliographical list. ....................... 32

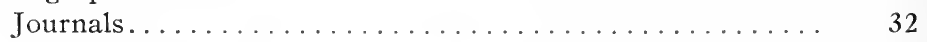

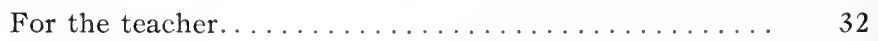

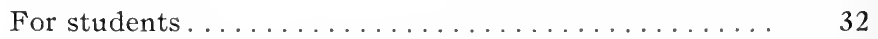

For student-use in the library .............. 32

American German daily papers.............. 32

The Library............................. 34-41

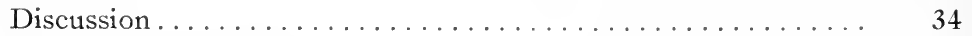

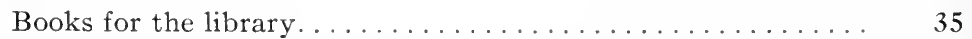

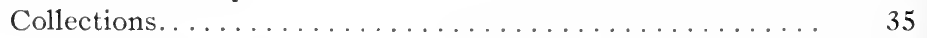

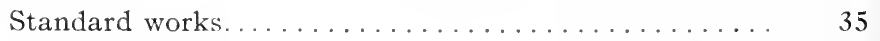

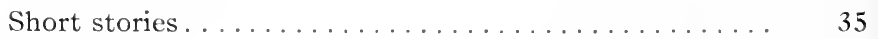

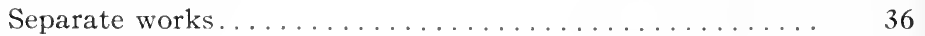

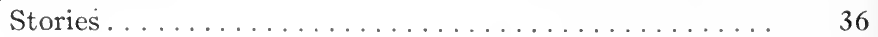

Plays............................... 39

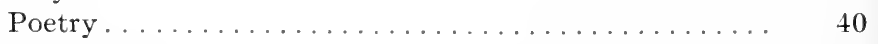

Reliable importers....................... 41 


\title{
BULLETIN FOR TEACHERS OF GERMAN
}

\author{
METHODS
}

\section{CHOICE OF METHOD}

Method in teaching is a way of reaching a given end by a rational, sequential arrangement of the facts of a subject and by employing such means as will secure that end in the most effective manner. No sane person will attempt to teach without some method. To become a slave to method, however, is nearly as bad as to use no method at all. We should not seek to teach the student method for the sake of method; we should use method solely as a means, so that the student may thereby acquire knowledge quickly and with understanding.

It should be perfectly obvious that the method of teaching is less important than the teacher himself. A good teacher, even if obliged to use a poor method, can hope for some success; a poor teacher will not succeed with the best method. There is, moreover, no such thing as a perfect method of language instruction, nor indeed any good method that is best for all teachers, all students, and all purposes. A teacher can use successfully only such a method as best fits his training, his knowledge, and his mastery over the language he is trying to teach to others. It is self-evident that a teacher who has an insufficiently fluent command of idiomatic spoken German is at a decided disadvantage in teaching by any oral method. The native-born German, or the American-born of German parents, often lacks a scientific knowledge of German grammar, and is therefore unable to teach with success by the Grammar-Translation Method.

Choice of method should depend to some extent also upon the purpose for which the students in a given class study German. Some desire to obtain only a reading knowledge of German, in order to use it as an aid in other subjects; others desire solely a speaking knowledge. But for the very great majority of students there should be a threefold aim: (1) a more or less fluent command of the spoken tongue; (2) ability to read readily and with understanding without translating; (3) ability to translate accurately into good English. Does any 
one question, however, that of these three points the first two are far more important than the third?

\section{DIFFERENT METHODS DEFINED}

We may speak in general of three different methods of language instruction, tho we often find modifications of each type, and also combinations of the different types.

- 1. The Grammar-Translation Method, with English as the usual medium

2. The Conversation Method, with German as the only medium

3. The Direct or Reading Method, with German as the medium, except perhaps when teaching composition

The Grammar-Translation Method may employ German to some extent, but it is distinctly not an oral method. The Conversation Method, rightly understood, is altogether an oral method. The Direct Method is distinctly an oral method, but written exercises can and ought to form a part of the grammar drill and of composition lessons.

\section{THE GRAMMAR-TRANSLATION METHOD}

The object of this method is a double one, drill in Grammar and skill in translation from German into English and from English into German.

It used to be thought that drill in grammar had a great disciplinary value, but modern psychologists no longer admit this. By this method it is possible to obtain a real mastery of a language. But this can not often happen, because of the very fact that the student is forced to learn grammar and not the living language itself. His attention is constantly called to the rules of a literary and grammatically correct language. $\mathrm{He}$ reads and knows classic German; the real modern living tongue, the spoken language of the Germans of to-day, he is in danger of never knowing. In consequence, the student comes to know literary German but not the every-day natural idiom.

After nine years of Latin study by this method few Germans can read Latin as Latin, fewer still can speak it. It is significant that in our own country protracted drill in grammar and 
composition has not noticeably improved the English of our children.

After a preliminary survey and drill in the essentials of grammatical forms the student is allowed to translate. No one will question the value of the power to translate accurately and with literary finish. But this is just the point where the Grammar-Translation Method, as generally used, fails most miserably of results. The reading matter is used as material for grammatical drill, and when composition is taught it has the same objective. Only after a long period of this drilling is the student permitted to give most of his attention to translating. In the meantime he has lost whatever Sprachgefühl he has gained by a more or less perfunctory "conversation exercise" from time to time. He ends by studying German literature, using a German text but reading it and thinking the content in English. He could do nearly as well if he used good translations in the first place.

By this method it is intended to give to students: (a) ability to translate accurately; (b) a better English style by comparing the grammatical structure and syntax of two languages, and by drill in translating into good literary English; (c) a knowledge of German literature, using English as the medium and thus transmitting the cultural value of German letters into English terms for English-thinking minds.

By the Grammar-Translation Method a student can rarely be made to acquire any real mastery of German as a living idiom. He can not hope to enter heart and soul into vital, intimate understanding of German thought and ideals as expressed by the masterpieces of German literature. To obtain such an understanding he must be able to read German as German, to feel "German," as it were, while he is reading it.

\section{THE CONVERSATION METHOD}

This method, as its name implies, aims to give to students a command of every-day, spoken German by oral drill in German itself. It is mainly a method of imitation, depending for its success upon endless repetition and upon memory. It ignores grammar almost entirely and tends to become more and more, as the work proceeds, a mere learning of phrases. All that the 
student acquires in the end is a weak, halting, uncertain, and, most often, very incorrect knowledge of some every-day idioms, phrases, and sentences. By this method, the student certainly gains very little additional power of thinking and is in danger of missing entirely the cultural value of German literary study.

\section{THE DIRECT OR READING METHOD}

The success of the Direct Method is due less to the fact that it is an oral method than to the fact that it places the emphasis upon reading without translating. Professor Walter in his book, Die Reform des neusprachlichen Unterrichts auf Schule und Universität, (Marburg, 1901), gives in a very brief form the essence of the Direct Method, in the following summary of Professor Viëtor's ideas.

"Nicht der tote Buchstabe, sondern das lebende Wort solle in den Vordergrund treten: die neuere Sprache sei nicht an einzelnen unzusammenhängenden Sätzen, sondern am lebensvollen Sprachstoffe zu erlernen und durch das Sprechen und die mündliche Verarbeitung des Sprachstoffes zum festen Eigentum des Schülers zu machen.

"Die Grammatik sei nicht mehr an erster Stelle zu erlernen, sondern habe als Abstraction der Sprache ihr gegenüber zurückzutreten und sei auf inductivem Wege aus dem gewonnenen Sprachstoffe abzuleiten. An die Stelle des bisher üblichen Uebersetzens aus der Muttersprache in die fremde Sprache müsse die freie Behandlung der Sprache wie im Wort, so auch in der Schrift treten.

"Vor allem zeigt Viëtor, wie wenig Wert man bisher auf die Aussprache gelegt habe, ja wie diese nach dem Wort seines Gesinnungsgenossen Prof. Dr. Trautmann in Bonn zum grossen Teil 'grauenvoll' sei, und zeigt uns den Weg eine genaue lautreine Aussprache zu lehren und wie hierbei stets vom Laut auszugehen sei."

If we analyze this statement, the following points stand out as the objectives of the Direct Method:

a. Detached, unconnected sentences, which were the ruling type in our German grammars up to a few years ago, can no longer be defended as pedagogically sound. The Direct Method demands a compact, connected, living, and natural Lesestück.

b. This Lesestück must form the basis of oral drill, question and answer, with German as the medium. If it is desired to reproduce the Lesestück in written exercises (i.e. composition) the student should be allowed to express the thought in a form that is natural and spontaneous. Only then will he express 
himself easily and without the restraint which a constant striving to fit his words into an authoritative, grammar-ruled form puts upon him. He will answer in terms of the living German as he has read it and heard it, and not in terms of the grammar.

c. The grammar is not to be studied before reading is begun. From the very first day the student is made to read without translating and the thought content of what he reads is developed into conscious knowledge by means of oral question and answer drill in German. The grammar, however, is not neglected; it is to be taught and learned inductively from the reading text by means of oral question and answer drill. Translation should be resorted to only in case the teacher is certain that this is necessary in order to give the student a clear understanding of a particularly involved or difficult passage in the text that $1 \mathrm{~s}$ being read.

\section{ADVANTAGES OF THE DIRECT METHOD}

1. The student is introduced at once to the language itself. He is forced to understand it and to speak it without first referring to his English, which he will certainly do if he has to think in terms of the grammar.

2. Stress is laid upon a good Aussprache from the start. The student can then best secure this because his mind is not confused and muddled by the demand to learn paradigms as such, and vocabularies, with all the vexations of genders and endings. He learns by hearing, by speaking, by writing. In other words, he can think what he reads and speaks and writes. He utters ideas, not forms.

3. He learns grammar as a means to an end, for the most part unconsciously. Drill in grammar does not take first toll of his strength and interest. Because he is forced to think in German, he feels in German. He gets this Sprachgefühl naturally, and with it acquires the necessary grammatical forms through actual use in thinking and speaking.

4. It strengthens the initiative of the student and gives spontaneity and pleasure to his mental faculties.

5. The student is first taught to speak of every-day things, but he is very soon ready to enter a wider field, the reading of good literature. No other method introduces him so quickly to reading. He knows this literature through the medium of the 
German language; he is not forced to translate. What he reads in German he feels as a German feels it, and he comes therefore to a deeper understanding and to a better appreciation of the best in the literature of the German people.

\section{DISADVANTAGES OF THE DIRECT METHOD}

1. There is a lack of properly trained teachers with a sufficiently good command of the spoken German. If a teacher can not speak German with ease he should not use the Direct Method entirely; but he should use it as far as he can. The important considerations are these: (a) He should not teach German as grammar, but as German, and (b) he should use German in the classroom as much as he can.

2. In the hands of some teachers the Direct Method tends to become a mere conversation method. It can not be emphasized enough that the Direct Method does not ignore grammar; it insists upon it as an integral and important part of the class work.

3. Many teachers do not realize that they must prepare a day's lesson much more carefully if they teach by the Direct Method than if they use the Grammar-Translation Method. In consequence one finds in the teaching in many schools a poor, haphazard, and illogical kind of questioning. All too often the teacher does most of the talking.

4. There is some difficulty in finding enough well-graded and interesting material in the text-book market. Nearly all publishers of German school-texts are, however, beginning to publish Direct-Method texts, so that abundant material will soon be at hand.

5. If care is not taken, the student's knowledge of grammar will lack system and coördination. This can be corrected by giving an out-and-out grammar lesson from time to time. But this should be done only after the student knows his grammar facts through inductive drill. A grammar lesson, as such, is intended to explain and to systematize what he already knows, not to teach him new grammar points. It is important that the student should be made to understand that this sort of a grammar exercise is a special class exercise and not the regular routine. 


\section{HOW TO TEACH BY THE DIRECT METHOD}

Most American teachers will modify the Direct Method in actual practice, and this is perfectly proper if it is done with common sense. Good teaching is in essence nothing more or less than applied common sense. Let the teacher make a study of the technique of Direct-Method beginning books: Such books are advertised by all the leading publishers of German text-books. The teacher should read also one or more of the treatises on methodology. A list of the best of these will be found in the bibliography under The Direct Method, page 8 . Especially recommended is Max Walter's German Lessons. This is a record of his work while Visiting Professor at the Teachers' College of Columbia University.

\section{BIBLIOGRAPHICAL LIST}

General. History of modern language instruction and bibliographical reference books.

Handschin, The Teaching of Modern Languages in the United States. U. S. Bureau of Education Bulletin No. \3, Series for 1913. Washington: Government Printing Office. Worth owning. Contains a good bibliography. (A supplementary bibliography may be found in the Monatshefte für Deutsche Sprache und Pädagogik, 1914, p. 332.) \$0.15.

Breul, Handy Bibliographical Guide to the Study of German. London: Hachette \& Company. 1895. Contains an extensive bibliography, tho somewhat out of date.

Viereck, Zwei Jahrhunderte deutschen Unterrichts in den Vereinigten Staaten. Braunschweig. 1903.

"Modern Languages," in Monroe's Encyclopedia.

\section{Theory and Practice}

The most important reference books under this heading are the following:

Bagster-Collins, The Teaching of German in Secondary Schools. New York: Columbia University Press. The Macmillan Company. 1911.

Bahlsen, The Teaching of Modern Languages. Boston: Ginn \& Company.

Breul, The Teaching of Modern Foreign Languages and the Training of Teachers. Cambridge [England]: University Press. 1909. (Putnam.)

Jespersen, How to Teach a Foreign Language. New York: The Macmillan Company. 1908.

Other valuable books are the following:

Bloomfield, The Study of Language. New York: Henry Holt \& Company. 1914. 
Brebner, Method of Teaching Modern Languages in Germany. New York: The Macmillan Company. 1904. 3rd ed. Valuable for its bibliographical lists of publications in Germany.

Methods of Teaching Modern Languages. Boston: D. C. Heath \& Company. 1893. A series of essays by noted American educators.

Report of the Committee of Twelve of the Modern Language Association of America. Boston: D. C. Heath \& Company. This report should be in the hands of every teacher of modern languages. $\$ 0.16$.

\section{The Gouin Method}

This is an important subject, because upon this method is based much of the theory and practice of the so-called Conversation Method and of the Direct Method.

Gouin, Francois, L'Art d'enseigner et d'etudier des langues. Paris. This book may be obtained in an English translation by Swan and Betis under the title, The Art of Teaching and Studying Languages. London: Scribner. 1892.

Kron, Die Methode Gouin oder das Serien-System. Marburg. 1900. This book may be obtained also in English translation. Marburg: N. G. Elwert.

The books of F. Thémoin, principal of the Gouin Schools in London, may be obtained through Brentano, New York, or McClurg, Chicago.

The Direct Method

Viëtor, Der Sprachunterricht muss umkehren. Heilbronn. 1905. This is the book that started the movement known as the Reform Methode, or Direct Method.

- Die Methodik des neusprachlichen Unterrichts. Leipzig. 1912.

Walter, Die Reform des neusprachlichen Unterrichts auf Schule und Universität. Marburg. 1911.

—_Z Zur Methodik des neusprachlichen Unterrichts. Marburg.

- German Lessons. A Demonstration of the Direct Method in Elementary Teaching. New York: Scribner. 1911.

To give here all the articles in the various periodicals that might be helpful or of interest would extend this bibliography beyond the purpose of this bulletin. A teacher who desires to make a special study of methods will find extended bibliographies in the books above, under the caption General. 


\section{PRONUNCIATION}

No one questions the importance of a good pronunciation, and experience has shown that this must be secured at the very beginning of the study of a language, otherwise the teacher will be confronted by the far more serious problem of getting his student to unlearn a bad pronunciation which has become fixed through habit.

After all, it is the teacher himself who is the best model and the best instrument of instruction. The use of a phonograph or similar talking machine is open to very serious objections, not the least of which is the impossibility of securing good records. Such an instrument is too mechanical to imitate successfully the intonation and the varying sentence stress of the natural voice. Furthermore, it is not every student who has an ear keen enough to imitate the sound he merely hears, and such a machine can never take the place of the teacher whose lips can be seen, and who can explain and show the position of the tongue while making any particular sound.

The teacher, then, must be able to pronounce correctly. $\mathrm{He}$ must know what is standard German and what is dialectic. Upon points like final "g," he must be inflexibly consistent, and not vary his pronunciation from word to word.

A knowledge of phonetics is indispensible to the teacher, not because he must teach it to the class, but that he may have a check upon his own pronunciation and be able to keep his own accent pure. How much use of the science of phonetics the teacher should make in the classroom depends upon the age of the students. The younger these are the less should they be taught the terminology and the principles of phonetics. But wherever imitation fails to produce the desired result in the teaching of any sound, the teacher should explain in a clear, simple and practical way how such a sound is made. Strict observation of the lips and the voice of the teacher on the part of the student, and vice versa, should be a matter of course. All too often the teacher is satisfied with a mere explanation or with the student's reproduction of the sound for the moment, 
and is not sufficiently insistent upon a correct reproduction every time a mistake is made. Often poor hearing of either teacher or student is responsible for bad pronunciation. Very often the teacher does not articulate distinctly. It is not so necessary that the teacher speak slowly as that he speak distinctly and plainly. Many helpful suggestions on how to teach pronunciation may be found in the books listed below.

\section{Standard German}

Siebs, Deutsche Bühnenaussprache. Berlin. 11th ed. 1912. Urgently recommended. $\$ 0.70$.

Bühnenaussprache. 2nd ed. 1901.

Grundzüge der Bühnenaussprache. A smaller edition of the above. Berlin-Köln-Leipzig: Ahn. 1900.

Viëtor, Aussprache des Schriftdeutschen. Leipzig. 8th ed. 1911. Very valuable. $\$ 0.40$.

- German Pronunciation. Leipzig. 1909. \$0.50.

Grandgent, German and English Sounds. Boston: Ginn \& Company. Very useful. $\$ 0.50$.

Douden, Orthographisches Wörterbuch der deutschen Sprache. LeipzigWien. Should be in the hands of every German teacher. $\$ 0.40$.

\section{Phonetics}

Hempl, German Orthography and Phonology. Boston: Ginn \& Company. 1897. Highly recommended. \$2.00.

Viëtor, Kleine Phonetik. 7 th ed. Leipzig.

- Elements of Phonetics. London: Rippmann. 1899. A translation of the Kleine Phonetik. Highly recommended.

ard treatise.

- Elemente der Phonetik. 5th ed. Leipzig. 1908. A stand- Deutsches Aussprachwörterbuch. Leipzig. Very valuable. $\$ 3.50$.

Prokosch, German Phonetics and German Language. New York: Henry Holt \& Company.

Sievers, Grundzüge der Phonetik. Leipzig. 1901. A standard treatise for advanced study.

Herrmann, Technik des Sprechens. Leipzig. 1903.

How to Teach Pronunciation

Viëtor, Wie ist die Aussprache des Deutschen zu lehren. Marburg. 1906. $\$ 0.15$.

Oberländer, Uebungen zum Erlernen einer dialektfreien Aussprache. Munich: 1901. Suggestive and helpful.

Consult also the books given under The Direct Method, page 8 .

Charts For Teaching Sounds

Deutsche Laultafel. System Viëtor. Marburg: E. G. Elwert. With 
explanatory pamphlet. $3 \mathrm{ft}$. by $4 \mathrm{ft}$. $3 \mathrm{in}$. The same chart on small card for 5 cents: these are for the student.

Rauschs Lauttafeln für den Sprachunterricht. Marburg: E. G. Elwert. For German, Series I, 20 charts: price about $\$ 8.00$. Series II, for French and English, 6 supplementary charts. Both series cost about $\$ 10.00$. These charts can be obtained on small cards, the whole series for about 60 cents.

Zund-Burguet, Die menschlichen Sprachwerkzeuge. A wall chart showing the organs of speech. With explanatory pamphlet. \$2.00. 


\section{GRAMMAR AND COMPOSITION}

\section{GRAMMAR}

The student has a right to expect a thoro drill in grammar for the purpose of using the knowledge thus gained to give him the ability to read, write, and speak German with a reasonable degree of accuracy and self-confidence.

Without a knowledge of grammar, progress beyond a certain point of proficiency in the use of very simple, ordinary, everyday expressions is difficult, if not entirely impossible. Without a knowledge of grammar the student is forced to rely almost entirely upon his memory, and he can never be entirely certain that he is correct in what he says, writes, or reads. There is often a subtleness of meaning and a refinement of thought in what he reads that he is in danger of never wholly understanding, or in what he wishes to say or to write that he finds himself unable to express.

It is equally important that the student should not be taught grammar for the mere sake of the grammar. He should know the facts and rules of the grammar and of syntax, but more than this, he should be so taught that he will acquire and use these more and more unconsciously. In other words, grammar should be so taught that the student gradually makes it a part of his mental equipment, so completely his own that he need rarely think of grammar as grammar, but will use it almost as naturally and as unthinkingly as when he expresses himself in his mother-tongue. Grammar should be for him not a body of rules and principles to which he must constantly refer; it should become for him of the very woof and warp of the language itself, something insepable from it.

The teacher will find it difficult to give to students, at least to the major portion of his class, such a knowledge of grammar and such a power of using it, and this very fact ought to make him take the teaching of grammar all the more seriously. One great mistake in the teaching of language, as we find it in school after school, is this very fact that grammar is taught as something apart from the language, so that it becomes for the stu- 
dent something distinct and separate. Such grammar instruction does not help,-it actually hinders,- - progress in acquiring the language. To follow a text-book, lesson for lesson, is never enough; for a text-book, no matter how well it is made, is a lifeless instrument. It is the teacher who must make grammar live.

The inductive teaching of the grammar, as used in the Direct Method, is more difficult for the teacher than the deductive procedure of the Grammar-Translation Method. There is always danger that the Direct-Method teacher will teach grammar rather indifferently; that he will in the end become more and more a Conversation-Method teacher, neglecting the grammar for the sake of the oral work. It is indeed a difficult problem to decide how much or how little grammar should be taught the first ycar.

There are also other important problems connected with the teaching of grammar. Many valuable hints and suggestions will be found in the books listed under the caption, Theory and Practice, page 7, which should guide not only the teacher's own practice but determine his selection of a proper text-book for his class. Helpful also is a comparative study of the best of the books for beginners.

That the teacher should himself know the grammar goes without saying, but for the help of those who feel the need of reference books on the subject, a list is given below, page 14 .

\section{COMPOSITION}

Composition, that is, formal and extended exercises in translating from English into German, should not be given until comparatively late in a student's course, certainly not much before the second year.

Composition exercises, elementary and advanced, should be based upon reading material already worked over in class by way of oral exercise, - at least for the first two years. Its aim should be, not to acquaint the student with new and additional grammatical facts, but to test his knowledge of grammar already acquired, and his ability to use this knowledge in a practical way.

Exercises of short, detached sentences, with little or no logical connection, should by no means be wholly avoided. It 
is only too true that this type of exercise has fallen into disrepute because in the past it has been used so much as a mere drill in vocabulary and grammar, with all else disregarded or neglected. But such exercises have a distinct value if used properly and not too often. Generally speaking, however, the connected, natural narrative should be the standard form of composition exercises. If taught purely for grammatical drill, there is great danger that any Sprachgefühl which the student may have acquired will be lost.

The many and difficult problems connected with composition will be found discussed in the books listed under Theory and Practice, page 7. See also the article by Koller, "Methods of Teaching Prose Composition," in the February and March numbers, 1914, of the Monatshefte für deutsche Sprache und Pädagogik. He gives there, also, a short bibliography of books on the subject.

\section{BIBLIOGRAPHICAL LIST}

\section{Reference Grammars for Teachers}

Curme, Grammar of the German Language. New York: The Macmillan Company. The best treatise in English on the subject. A valuable book for the teacher's own library. \$3.50.

Behaghel, Short Historical Grammar of the German Language. Translated by Trechmann. London. 1891. (Macmillan.)

Wright, Historical German Grammar. New York: Oxford University Press.: 1907. 1891.

Lyon, Handbuch der deutschen Sprache für höhere Schulen. Leipzig.

Sütterlin, Die deutsche Sprache der Gegenwart. 3rd ed. Leipzig. 1910. Valuable.

Useful and valuable are the more extended chapters or parts of such school grammars as:

Thomas, Practical German Grammar. Revised. New York: Henry Holt \& Company.

Joynes-Meissner, German Grammar. Boston: D. C. Heath \& Company.

Whitney, A Compendious German Grammar. New York: Henry Holt \& Company.

Helpful and Related Books

von Jagemann, Elements of German Syntax. New York: Henry Holt \& Company. 
Grunow, Grammatisches Nachschlagebuch. Ein Wegweiser für jedermann durch die Schwierigkeiten der deutschen Grammatik und des deutschen Stiles. Leipzig. 1905.

Sanders, Wörterbuch der Hauptschwierigkeiten in der deutschen Sprache. Langenscheidt. Berlin-Schöneberg. 1908. Highly commended.

Wessely, Deutscher Wortschatz. Grammatisch-stilistisch-orthographisches Handwörterbuch. Gotha: Schmidt. 1912. Very helpful.

Hastings, Studies in German Words and their Uses. Boston: D. C. Heath \& Company. 1911. Suggestive on building up of vocabularies.

Walter, Die Aneignung und die Verarbeitung des Wortschatzes.

Taker and Roget, German Idioms. New York: The Macmillan Company.

Lambert, Handbook of German Idioms. New York: Henry Holt \& Company. 1910.

Wilkins, German Idioms. Minneapolis: The H. W. Wilson Company. 1901.

The following dictionaries are also useful for grammar reference:

Eberhard-Lyon, Synonymisches Handwörterbuch der deutschen Sprache. Leipzig: Grieben. Wien.

Douden, Orthographisches Wörterbuch der deutschen Sprache. Leipzig-

Kluge, Etymologisches Wörterbuch der deutschen Sprache. Strassburg: Teubner. 


\section{PRACTICE IN SPEAKING}

First-year books, as a rule, contain sufficient material for ordinary class work in oral drill. The lessons in nearly all such books have as their object, however, not only oral drill but also the acquisition of grammatical forms and principles. Only the very experienced teacher should ever undertake to conduct a class without a text-book to guide him. It is not always necessary that the text-book should also be in the hands of the students. Indeed, it is a good idea, provided the teacher is capable of so doing, not to let the class have a book at all for the first few weeks; but in such a case the teacher may well keep in mind the preliminary lessons of the text-book he intends later to give his class.

After the student is able to read easily material more or less literary in character, or reading matter that has been put together with a pedagogical purpose but which is more extended in scope than the earlier reading, and has also greater freedom of expression and some pretense to literary style, there comes a time when exercises more largely conversational in purpose become desirable. Good reading material upon which to base conversational work is furnished by such text-books as those listed under "Land und Leute," page 18, books that were made for this very purpose. But the teacher should use care in the selection he makes, for these books are not all of the same grade of difficulty, or equally valuable.

Supplementary to all such reading material, and at almost any stage of the student's progress, is the proper use of what is known as "Anschauungs-material." This consists of wall charts depicting scenes of German life, pictures, post cards, lantern slides, and the like. Valuable also is the playing of games and the learning and presentation of short plays. Singing of German songs and recitations strengthen the memory and help the pronunciation, if properly directed. All such devices doubtless help to create that subtle thing we call "German atmosphere," and if entered upon with zeal and enthusiasm, and under careful direction by the teacher, do create interest and draw the student away from the humdrum monotony of daily drill in the text- 
book lessons. When far enough advanced, the student can be set to reading various books on "Land und Leute" and be asked to make reports orally or in writing of what he has read. See list of books below under "Land und Leute," page 18.

Suggestions and advice on this subject may be obtained in the Theory and Practice. Allen's Hints on German Conversation, (Ginn \& Company, Boston), will be found useful. It costs ten cents.

\section{SOME "DON'TS" FOR THE TEACHER}

Don't do most of the talking yourself. Give the students a chance.

Don't confine yourself to questions and the students to answers.

Don't expect your class to talk on subjects for which it does not possess a fair command of the necessary vocabulary.

Don't make your questions monotonous. Bring variety into your work.

Don't let your questions be haphazard. See that there is a logical sequence, a purpose, and an aim.

Don't ask questions that can be answered by a simple "yes" or "no." This form of questions will be necessary at the very beginning so that the student may imitate the teacher, by turning a simple question into a declaration form, but should not be used after the first few weeks.

Don't kill the initiative and spontaneity of your students by requiring an answer in just such-or-such a form.

Don't let your class lapse into English. Keep the students so busy with rapid-fire questioning that they will not have time to think in English.

How to question is one of the most difficult matters for the average teacher to learn and some of the class-room work in this particular is disheartening. A study of the Gouin method (see list of books on page 8), comparisons of text-books, and a fair measure of common sense should help the teacher. 


\section{ILLUSTRATIVE MATERIAL}

LAND UND LEUTE

\section{General}

Most of these books are too expensive for the student to buy, but they are valuable books for the school library.

Baring-Gould, Germany, Past and Present. 2 vols. London. 1879. Tho not up-to-date, this book contains much that is interesting and valuable. Hull.

Dawson, Germany and the Germans. 2 vols. London: Chapman \&

- German Life in Town and Country. New York: Putnam.

Collier, Germany and the Germans. New York: Scribner. 1914.

King, Three Free Cities. Hamburg, Bremen, Lübeck. Illustrated. E. P. Dutton.

Kron, Bilder des Deutschen Lebens und Wesens. Karlsruhe. 1905.

Schultz, Deutsches Leben im I 4ten und I5ten Jahrhundert. Illustrated. Prag-Leipzig. 1892.

Grueber, Myths of Northern Lands. New York: Dodd, Mead \& Co. 1902.

- Stories of Wagner Opera. New York: Dodd, Mead \& Company.

Dickie, In the Kaiser's Capital. New York: Dodd, Mead \& Company.

Schauffler, Romantic Germany. Illustrated. New York: Century Company. 1909.

Bartley, The Rhine from its Sources to the Sea. 2 vols. Illustrated. Philadelphia: J. C. Winton Company.

Müller-Bohn, Des Deutschen Vaterland. 2 vols. Stuttgart. 1913.

Sedgewick, Home Life in Germany. Illustrated. New York: The Macmillan Co. 1908.

Land und Leute, Monographien zur Erdkunde. Profusely illustrated. (Thüringen, Tirol, Oberbayern, Harz, Rhein, Schwarzwald, Nordseeküste, Ostseeküste, Berlin, Dresden, etc.) Each set about \$1.20.

Vellhagen und Klassing, Volksbücher. A series similar to the Land und Leute, but very cheap and of course not so good. Each Volksbuch, about $\$ 0.15$.

Degener, Wer ist's. Leipzig. The German "Who's Who."

To this list may be added such American text-books as the following:

Bacon, Im Vaterland. Boston: Allyn \& Bacon.

- Vorwärts. Boston: Allyn \& Bacon. 1915.

Holzwarth, Gruss aus Deutschland. New York: Henry Holt \& Company.

Mosher, Willkommen in Deutschland. D. C. Heath \& Company.

Allen, German Life. New York: Henry Holt \& Company. 
Illustrated and of Historical Interest

Das Kaiserbuch. Acht Jahrhunderte deutscher Geschichte. Berlin: Muckenberg.

Die eiserne Zeit vor Hundert Jahren. I813-15. Leipzig: Siwinna.

Germania, Zwei Jahrtausende deutsches Lebens. Union Verlagsgesellschaft. Berlin: Stuttgart.

STORY AND LEgEND

Walhall, Götterwelt der Germanen. Berlin: Oldenburg.

Urvaterhort, Heldensagen der Germanen. Berlin: Oldenburg.

Jensen, Der Schwarzwald. Leipzig: Amelangs Verlag. 1901.

Thüringer Wald. Berlin: Skopnik.

Deutsche Volkstrachten. Leipzig: Bach Verlag.

\section{POSTCARDS, PHOTOGRAPHS, PICTURES}

Write for catalogs and make inquiries of the following firms. Most of them have post cards from five cents up, also prints and more expensive pictures.

Berlin Photographic Company, 305 Madison Ave., New York. American agents for the Berlin Photographische Gesellschaft.

Jones-Keyser Company, 142-146 West 24th St., New York. American agents for the Neue Photographische Gesellschaft, Berlin.

Atkinson, Mentzer \& Company, 318 West Washington St., Chicago. American agents for B. G. Teubner of Leipzig. Send fifteen cents for a list of "Künstlersteinzeichnungen," a large series of reproductions of paintings. These are excellent for school decorations.

The Art Institute of Chicago publishes a number of colored prints and post cards of masterpieces of art.

Georg. D. W. Callwey, Munich, Germany, has a fine series of "Meisterbilder" that cost about ten cents each.

\section{WALL PICTURES, CHARTS, FOR CONVERSATION DRILL}

These can be obtained through such firms as G. E. Stechert, New York, and Atkinson, Mentzer \& Company, Chicago.

Hoetzels Anschauungsbilder. Large wall chromolithographs, some twenty in number. They cost about $\$ 1.50$ each. The subjects are Spring, Summer, Autumn, Winter, The Farm, The Mountain, The Forest, The City, The Home, The Harbor, and a number of cities, such as Paris, London, Vienna, Berlin. Some of these charts are published in book size for home study by the student. They are folded into pamphlets containing vocabulary and conversation drill on each picture. Such a pamphlet costs about fifteen cents.

Hirts Anschaunngsbilder. A series similar to the above, consisting of some eight pictures: Spring, Summer, Autumn, Winter, Mountains, Forest, City, Harbor. These can be had in book size, the whole series together for about twenty cents. 
Hey-Spekter Märchen Bilder. Made by Perthes, Gotha. Very artistic. Good for school decoration. Each \$0.60.

Lehmanns Kulturhistorische Bilder. These are small pictures, about 24 by 30 inches. They number about twenty-five and are mostly on medieval subjects. In colors and very artistic.

The catalogs of the following firms are especially helpful:

B. G. Meinhold Söhne, Dresden.

B. G. Teubner, Leipzig.

F. E. Wachsmuth, Leipzig.

R. Voigtländer, Leipzig.

\section{MISCELLANEOUS}

Catalogs of various German firms can be secured and articles desired can be bought direct or through:

G. E. Stechert \& Company, New York.

A. J. Nystrom \& Company, Chicago.

Write for catalogs to

K. F. Koehler, Leipzig (Bibliotheca Pädogogea, Verzeichnis der bewährtesten Lehrmittel).

F. Volkmar, Leipzig.

Dr. Oscar Schneider, Leipzig.

B. G. Teubner, Leipzig.

Simon Schropp'sche Landkarten-Handlung, Berlin.

Send twenty-five cents to the National German-American Teachers' Seminary, Milwaukee, Wis., for list of recommended illustrative material.

\section{MAPS AND CHARTS}

Inquiries can be made and maps ordered through Rand, Mc. Nally \& Company, Chicago and New York, and A. J. Nystrom \& Company; Chicago. Excellent map-makers are the following:

Geographical Maps

Richard Kiepert, Berlin.

Justus Perthes, Gotha.

Richard Andree, Bielefeld und Leipzig: Velhagen und Klassing.

Historical MAPS

Kühnert, Spruner-Bretschneider, and Ed. Gaebler are especially recommended.

MAPS FOR WILHELM TELL

Vogt and by Rein.

MAPS FOR JUNGFRAU VON ORLEANS

Teetz. 


\section{LANTERN SLIDES}

Most German stereopticon firms deal also in lantern slides. Catalogs will be sent upon application, in most cases gratis. Among the best German firms are:

Dr. Franz Stoedtner, Universitätsstrasse 3, Bcrlin.

ICA Actien Gesellschaft, Dresden.

Unger \& Hoffmann, Dresden.

The following American firms also sell slides or are prepared to make them to order:

McIntosh Stereoptican Company, Chicago, Ill.

T. H. McAllister Company, 49 Nassau St., New York City.

Underwood \& Underwood, New York City.

Williams, Browne \& Earle, Philadelphia, Pennsylvania.

A large and valuable number of slides are offered for sale by Anna Bernkopf, 503 West 121st St., New York City. Write for list.

The very best way to secure such a collection as one may want is to have the slides made from selected illustrations. Good slides can be made from illustrated post cards, from pictures, photographs, and illustrations in books and periodicals.

Good reliable slide makers are to be found in nearly all of the larger cities. Write for estimates to the following:

Miss Margaret Sheridan, 89 S. 10th St., Minneapolis.

George B. Swain, Ann Arbor, Mich.

Prof. F. J. Menger, 1346 Grand Ave., St. Paul, Minn.

\section{GAMES}

Most card games and toy games are too juvenile for highschool students. Address inquiries to W. R. Jenkins, New York; G. E. Stechert, New York; A. C. McClurg, Chicago. Holtzermann's Chicago Store, 417 Cedar Ave., Minneapolis, has many German games and toys at Christmas time.

Almost any English game can be played in German: such as Game, Fish, or Fowl; Charades, etc.

\section{SONGS}

The number of song collections of one kind or another is almost endless. It is well to consult the dealer of music publications. The most popular and serviceable collections made for American schools are the following:

Deutsches Liederbuch für Amerikanische Studenten. Boston: D. C. Heath \& Company. Highly recommended. $\$ 0.75$. 
Walter-Krause, German Songs. New York: Scribner. \$0.50.

The best German collections are the following:

Schauenbergs Allgemeines Deutsches Kommersbuch. Lahr: Germany. This is a standard student collection and contains 850 songs with the melodies only.

200 Lieder aus dem Lahrer Kommersbuch mit Klavierbegleitung. Lahr: Germany. This contains two hundred songs of the Schauenberg Kommersbuch. $\$ 1.50$.

A number of American text-books contain some songs with the music:

Bacon, Im Vaterland. Boston: Allyn \& Bacon. Has about iwenty songs.

Schlenker-Juergensen, Deutsche Gedichte. Minneapolis: Northwestern School Supply Company. Contains about twenty songs, with music.

Wenckebach, Die schönsten deutschen Lieder. Contains about twenty songs, with music.

Burkhard, Poems for Memorizing. New York: Henry Holt \& Company. Ten songs with music.

\section{PLAYS FOR ACTING}

In selecting a play for presentation by a class, the teacher should consult not only the histrionic abilities of his students, but also their ability to use the German of the play intelligently. Some plays are better fitted for more advanced students and should not be forced upon less advanced ones. Probable interest in the plot and the effectiveness of a play when acted are also important considerations. Purely "literary" plays should be avoided.

Benedix, Haustheater. 2 vols. Leipzig: J. J. Weber. 1891. This excellent collection contains 46 plays; 43 are of one act each, 3 are of two acts each. Of the plays in this collection, a number have been published separately by American book firms. These plays cost from 25 to 35 cents each.

Nein. D. C. Heath \& Company.

Der Prozess. D. C. Heath \& Company, Henry Holt \& Company.

Die Hochzeitsreise. D. C. Heath \& Company.

Günstige Vorzeichen. (In Well's Drei kleine Lustspiele.) D. C. Heath \& Company.

Eigensinn. (Published with Einer muss heiraten.) Henry Holt \& Company.

Der Dritte. Henry Holt \& Company.

Plautus und Terenz. Sonntagsjager. Published in one book. D. C. Heath \& Company. 
Other good plays of one or two acts follow. These cost from 25 to 40 cents each.

Elz, Er ist nicht eifersüchtig. D. C. Heath \& Company.

Wells, Drei kleine Lustspiele: Benedix, Günstige Vorzeichen and Der Prozess. Wilhelmi, Einer muss heiraten. D. C. Heath \& Company.

Hervey: Benedix, Der Prozess. Fulda, Unter vier Augen. Henry Holt \& Company.

Hervey: Wilhelmi, Einer muss heiraten. Benedix, Eigensinn. Henry Holt \& Company.

Rosen, Ein Knopf. Henry Holt \& Company.

Moser, Der Schimmel. Henry Holt \& Company.

Man'ey and Allen, Four German Comedies. Rosen, Ein Knopf. Moser, Ein amerikanisches Duell. Müller, Im Wartesaal erster Klasse. Pohl, Die Schulreiterin. Ginn \& Company.

Moser, Der Bibliothekar. D. C. Heath \& Company.

Wichert, Als verlobte empfehlen sich. D. C. Heath \& Company.

Short German Plays. Clarendon Press. Series 1 costs 50 cents, series 2, 60 cents.

F. Diederik, Theaterstïcke für Dilettantenbühnen. Flugschrift No. 3 des Dürerbunds. Munich: Georg. D. W. Callwey. Contains a number of good suggestions.

There are a number of Märchendramen of more or less doubtful value. See catalogs and make inquiries of G. E. Stechert or W. R. Jenkins Company, New York. 


\section{WHAT TO READ}

First year or beginning books on the Direct-Method plan usually have reading material for the first year at least, but for the sake of variety and the encouragement of the students it is well to use also some suitable text consisting of short stories or a longer short narrative. A so-called reader can be used acceptably in place of this, especially if the beginning book is based on the Grammar-Translation Method.

In either case the choice of reading material should be dictated by some or all of the following considerations:

1. The text selected should not be more difficult, or only a little more difficult, than the reading lessons in the beginners' book. It is folly to try to read anything the student is not prepared to undertake.

2. The vocabulary should be carefully considered. It should not contain too large a number of words, or words that are not in common every-day use. As the student advances into the upper years this consideration becomes less and less important, but it should carry great weight in the first two years.

3. Only books really worth-while should be considered. The time is too short to waste a student's efforts on trash. We should aim to give the student something beyond the mere language, something that has educative and cultural value.

4. The probable interest of the student is of prime importance, for a dull book makes a dull class in spite of all the best efforts of a good teacher. The age, maturity of mind, home environment, and the average cultural standard of the entire class must be taken into account. Not all stories are equally interesting to boys and to girls.

5. The length of the story is important. For the beginner a number of short stories is best, and in advanced classes the text of not over one-hundred pages is to be preferred. The students simply tire of a long story which must be read piece-meal.

6. The story should be in real German and written preferably by a German. Only a very few of the constructed storytexts have proven worth while.

7. In general, fiction or drama is most likely to furnish the 
best reading material; but history and biography may well find a place in a course of more than two years.

8. Poetry should not be neglected; that is, collections of short poems and of ballads. The latter lend themselves to oral work. A fair amount of poetry and of songs should be memorized. Often such pieces are among the most cherished possessions of a student in later years when he has all but forgotten what he was taught in school.

9. The reading of the so-called classics should be deferred as long as possible. Before the student is ready to read them he should have had a great deal of prose reading, possess a good command of a fairly comprehensive vocabulary and a firm knowledge of German forms and syntax. If students have to read Wilhclm Tell, the very best classic for early reading, by painfully translating it little by little, with a constant appeal to the dictionary, they are not ready for it.

10. Under no condition should the text selected be one that the teacher himself has not read with care and with an eye to its suitability for the particular class for which a text is sought. Most of the mistakes in selecting texts arise from the fact that the teacher has chosen by title, or because of the author, or on somebody's advice. Indeed, it is always a good idea to re-read a text before selection, if one's impression as to its difficulty and availability is not clearly remembered.

11. It is a mistake to read only one kind of material, such as short stories. As in other things, variety is the spice of life.

12. The sequence of texts in a course of two, three or four years should also weigh in the selection of a text for any particular stage or year. It is not necessary that this plan be so specific that every text must be determined beforehand, but a general plan having as its aim a graded sequence, variety, and progress in educative and cultural value, should be clearly in the teacher's mind. American text-book publishers have in their catalogs made graded lists of texts for the respective years for which their books are best suited.

The leading publishers are the following:

Allyn \& Bacon, Boston.

American Book Company, New York.

Ginn \& Company, Boston.

D. C. Heath \& Company, Boston. 
Henry Holt \& Company, New York.

The Macmillan Company, New York.

C. E. Merrill Company, New York.

Oxford University Press, Scribner, New York.

Scott, Foresman \& Company, Chicago.

Helpful also are the lists in "Zur Jugendschriftfrage," Leipzig, 1903, a report of the Vereingte deutsche Prüfungsschüsse für Jugendschriften.

\section{DICTIONARIES}

\section{A. FOR STUDENT USE}

German-English English-German

Bellow's New German-English and English-German Dictionary. New York: Henry Holt \& Company. \$1.75.

Heath's German Dictionary. (The Cassel's German Dictionary.) Boston: D. C. Heath \& Company. \$1.50.

James's Dictionary of the English and German Language. New York: The Macmillan Company. \$2.00.

Langenscheidts Taschen Wörterbücher. English-German, 1 vol.; German-English, 1 vol. Berlin: Schöneberg. Small print but clear. Excellent. The two volumes together, $\$ 1.00$. Single volume $\$ 0.60$.

Muret-Sanders' Enzyklopädisches Wörterbuch der englischen und deutschen Sprache. Hand und Schulausgabe. Langenscheidt. Berlin: Schöneberg. 1909. Highly recommended. This is a smaller edition of the dictionary of the same name given below. $\$ 2.50$.

Whitney's Compendious German and English Dictionary. New York: Henry Holt \& Company. $\$ 1.50$.

German-German. All the definitions given in German.

Sanders Handwörterbuch der deutschen Sprache. Leipzig. 1910. $\$ 2.50$.

Venns Deutsches Wörterbuch. Leipzig: Bergner. 1905. Good tho small. $\$ 0.75$.

\section{B. FOR TEACHERS AND THE LIBRARY}

Flïgels Allgemeines Englisch-Deutsches und Deutsch-Englisches Wörterbuch. 3 vols. Braunschweig: Westermann. 4th ed. 1908. A standard work. $\$ 12.00$.

Grieb-Schröer Englisch-Deutsches und Deutsch-Englisches Wörterbuch. 2 vols. Menter-Verlag. Berlin: Schöneberg. A standard work. Old spelling. $\$ 4.50$.

Muret-Sanders Enzyklopädisches Wörterbuch der englischen und deutschen Sprache. Grosse Ausgabe. 2 vols. Langenscheidt. BerlinSchöneberg. The best of all German-English dictionaries. $\$ 10.00$. 
Wiegands Deutsches Wörterbuch. 2 vols. 5th ed. Giessen: Topelmann. 1909. A standard, and highly recommended.

Brockhaus Konversations-Lexikon. 16 vols. Leipzig.

\section{FOR SPECIAL PURPOSES}

The following serve special purposes, as is indicated by their titles. All are highly recommended.

Dudens Orthographisches Wörterbuch der deutschen Sprache. LeipzigWien: Should be owned by every teacher. $\$ 0.40$.

Eberhard-Lyons' Synonymisches Handwörterbuch der deutschen Sprache. Leipzig: Grieben. \$3.50.

Kluges Etymologisches Wörterbuch der deutschen Sprache. Strassburg: Trübner. 8th ed. 1914. \$1.50.

\section{TECHNICAL DICTIONARIES}

Egers Technologisches Wörterbuch. 2 parts. Braunschweig: Brandes.

Lang's German-English Dictionary. Philadelphia: Blakiston. A dictionary for students of science and medicine. $\$ 4.00$.

\section{REFERENCE BOOKS ON GERMAN LITERATURE}

\section{A. GENERAL HISTORIES OF GERMAN LITERATURE}

WORKS OF ONE Volume

All of these are of almost equal value and all are standard works.

Francke, History of German Literature. New York: Henry Holt \& Company. 1908. This is not a chronological or biographical account, or a survey of individual authors and writings, but an appreciative and excellent presentation of the social significance of literary epochs at different periods. The book should be in every school library.

Hosmer, History of German Literature. New York: Scribner. 1911.

Priest, Brief History of German Literature. New York: Scribner. 1909.

Robertson, History of German Literature. New York: Putnam. 1908. Rather detailed for high-school students, but an excellent reference book. Should be in the school library.

Outlines of the History of German Literature. Putnam. This is an excellent student edition of Robertson's History of German Literature. 1909.

Thomas, German Literature. New York: Appleton \& Company.

Vögtlin, Geschichte der deutschen Dichtung. Zürich: Schulthess \& Company. 2nd ed. 1913. One of the best of the shorter histories.

Works of More Than One Volume. All standard works.

Bartels, Geschichte der deutschen Literatur. 2 vols. Leipzig. 
Meyer, J., Einführung in die deutsche Literatur. 6 vols. Berlin. 1909. Extensive, but one of the most valuable reference works. It contains sources, critiques, and analyses of all the most important literary products of German writers. Should be in the school library.

Scherer, Geschichte der deutschen Literatur. 2 vols. Berlin. Also translation by Conybear. 2 vols. Oxford [England]: Clarendon Press. A standard work, tho not brought down to date.

Vogt und Koch, Deutsche Literaturgeschichte. Illustrated. 2 vols. Leipzig and Vienna. 3rd ed. 1910. One of the best books for general reference.

\section{B. HISTORIES OF NINETEENTH CENTURY LITERATURE}

Biese, Deutsche Literaturgeschichte. 3 vols. Munich: Beck. 1907.

Brandes, Die Hauptströmungen der Literatur des Ioten Jahrhunderts. From the Danish. 2 vols. 6th ed. Leipzig. 1899.

Main Currents in Igth Century Literature. An English translation of the above. London. 1901-05. This is a general history of the world's literature, but contains excellent chapters on German literary movements in the nineteenth century.

Gottschall, Deutsche National Literatur des Ioten Jahrhunderts. 2 vols. Breslau. 1901.

Kummer, Deutsche Literaturgeschichte des Igten Jahrhunderts. Dresden: Reissner. 1911. Up-to-date and very highly recommended for the school library.

Meyer, R. M., Die Deutsche Literatur des Igten Jahrhunderts. Berlin: Bondi. 1912.

\section{ANTHOLOGIES}

Collitz, Selections from Classical German Literature. Oxford Press. 1914.

Müller, Max, German Classics from the Fourth to the Nineteenth Century. 2 vols. New York: Scribner.

Thomas, Anthology. Boston: D. C. Heath \& Company. 1914.

\section{HELPFUL BOOKS}

Boyeson, Essays in German Literature. New York: Scribner.

Francke, German Ideals of Today. Boston and New York: Houghton, Mifflin \& Company. 1880 .

Hillebrand, German Thought. New York: Henry Holt \& Company.

Japp, German Life and Literature. London.

Nollen, Chronology and Practical Bibliography of Modern German Literature. Chicago: Scott, Foresman \& Company. 1903.

Taylor, Studies in German Literature. New York: Putnam. 1902.

Krüger, Deutsches Literatur-Lexikon. Biographisches und Bibliographisches Handbuch mit Motiven-Uebersichten-und Quellennachweisen. Munich: Beck. 1914. 
Könneke, Bilderatlas zur Geschichte der Deutschen National Literatur. 1675 illustrations. Marburg. 1912. Contains reproductions of photographs of leading authors, of manuscript pages and pages of first editions, and other interesting and valuable material. An excellent book for the school library.

Degener, Wer ist's. Leipzig. The German "Who's Who."

\section{E. THE CLASSIC WRITERS}

LESSING

Rolleston, T. W., Life of G. E. Lessing. Great Writers Series. London. 1889.

Sime, J., Lessing. 2 vols. London. 1890.

Schmidt, E., Lessing: Geschichte seines Lebens und seiner Schriften. 2 vols. Berlin. 1892. A standard work.

Stahr, A., G. E. Lessing. Sein Leben und seine Werke. 9 th ed. Berlin. 1887. Also translation in English by E. P. Evans. Boston. 1866.

Goethe

Boyeson, Goethe and Schiller. Scribner. 1907. Excellent. Should be in the school library.

Lewes, Life of Goethe. London. 4th ed. 1890.

Sime, Life of Goethe. London. 1888.

Bielschowski, Goethe, sein Leben und seine Werke. 2 vols. Munich. 15th ed. 1909.

The Life of Goethe. Translation by Cooper. 3 vols. New York: Putnam. 1908. A standard work.

Heinemann, Goethe. 2 vols. Leipzig. 3rd ed. 1909. A standard work.

Meyer, R. M., Goethe. 2 vols. 3rd ed. Berlin. 1905. A standard work.

\section{SCHILLER}

Boyeson, Goethe and Schiller. Scribner. 1907. Excellent. Should be in the school library.

Nevison, Life of Schiller. London. 1887.

Thomas, Life and Works of Schiller. New York: Henry Holt \& Company. The best English biography. Should be in the school library.

Minor, Schillers Leben und Werke. 2 vols. (Incomplete.) Berlin. 1890. A standard work.

Kühnemann, Schiller. Munich. 1905.

Excellent.

Schiller. Translation by Royce. 2 vols. Ginn \& Company.

Wychgram, Schiller. Leipzig. 5th ed. 1906. Profusely illustrated. Very valuable on account of the illustrations.

Palleske, Schillers Leben und Werke. Stuttgart. 1891. 13th ed. A standard work. Lady Wallace. London. 


\section{REFERENCE BOOKS FOR GERMAN HISTORY}

GENERAL

Henderson, History of Germany. 2 vols. The Macmillan Company. 1906. Poplar and interesting. Also shorter, one-volume edition of the above. New York: The Macmillan Company.

Kohlrausch, History of Germany. Translated by Haas. New York: Appleton \& Company.

Holland, Germany. Making of the Nation Series. Illustrated. New York: The Macmillan Company.

Lewes, A History of Germany. Based on Müller's Geschichte des deutschen Volkes. American Book Company.

Müller, Geschichte des deutschen Volkes. 18th ed. Berlin. 1902.

Menzel, History of Germany. Translated from the German. 3 vols. New York: The Macmillan Company. 1875.

Sime, History of Germany. New York: Henry Holt \& Company.

Müller, History of Recent Times. With special reference to Germany. New York: Harper. Excellent. Only from 1815 to 1880.

Bigelow, History of the German Struggle for Liberty. 4 vols. New York: Harper. Takes up only the first half of the nineteenth century.

Priest, Germany since I740. Boston: Ginn \& Company. 1914.

\section{RELATED BOOKS}

Baring-Gould, Germany. 2 vols. London. 1879. Out of date, but valuable in parts.

Collier, Germany and the Germans. New York: Scribner. 1914.

Burt, The German Empire. Illustrated. New York: The Macmillan Company.

Dawson, Germany and the Germans. 2 vols. London: Chapman \& Hull.

Dawson, The Evolution of Modern Germany. New York: Scribner.

Francke, German Ideals of Today. Boston and New York.

Hillebrand, German Thought. New York: Henry Holt \& Company. 1880 .

Müller-Bohn, Des Deutschen Vaterland. Illustrated. 2 vols. Stuttgart. 1913.

Schauffler, Romantic Germany. Illustrated. New York: Century Company. 1909.

See also books listed under Land und Leute, page 18. 


\section{THE SELF-IMPROVEMENT OF THE TEACHER}

The teacher who does not constantly seek to improve his methods of instruction and to increase his knowledge of the subject he is teaching is blind to his own best interests and disloyal to the highest ideals of his profession. As far as time and means allow he should make use of some, if not all, of the avenues of progress open to him.

1. He should possess in his own library some representative books dealing with methods, history of German literature, political history of Germany, and a few, at least, dealing with German life, institutions, and customs.

2. He should take some technical journal for teachers of modern languages. See list on page 32 .

3. He should lay out for himself, if possible with the advice of some one more expert than himself, a course of reading and intensive study.

4. Membership and an active interest in the meetings of the modern language section of the State Educational Association can serve him by giving him a chance to exchange ideas and to learn from the experiences of others.

5. He has the right to become a member of the Modern Language Association of America, the Teachers' Alliance, and other national organizations.

6. Summer study can be carried on at a number of American universities. In making his choice of a college or university for summer work, he should be guided by the character, the kind, and the number of courses offered, and by the personnel of the department. In other words, he should have a definite idea as to what he wants or needs to study. Excellent training can also be obtained at such a school as the German-American Teachers' Seminary in Milwaukee, Wis.

7. Study abroad for a year or more is highly desirable. If an extended stay in Germany is not possible, a summer can be spent there with profit. For those who do not possess a fluent command of spoken German, it is best to go abroad with some study-party under competent teacher-guides, or to 
spend most of the time at a summer session of one of the German universities.

\section{TRAVEL-STUDY CLUBS}

Boston Travel Society, 601 Boylston St., Boston.

Bureau of University Travel, Trinity Place, Boston.

A number of University of Minnesota graduates have reported very favorably on their experience with travel-study parties organized and conducted by Professor Charles H. Stomberg, University of Louisiana, Baton Rouge, Louisiana.

In reputable American journals there are always a number of advertisements of other travel-study clubs. It is, however, always a wise measure to investigate thoroly before joining.

\section{SUMMER SESSIONS ABROAD}

Summer sessions are offered at a number of German universities, such as Jena, Marburg, Freiburg-in-Baden. For statement of courses, fees, etc., write to the Sekretariat der Ferienkurse of the respective universities. The summer semester of all German universities begins late in April and lasts until the first of August, so that, if it is possible to get an earlier start from America, it is feasible to spend the major portion of a regular semester at any German university. The VorlesungsVerzeichnis can be obtained at small cost from any importer of German books.

\section{JOURNALS}

A. FOR THE TEACHER

Journals largely more Professional than Literary and PhiloLOGICAL

Monatshefte für deutsche Sprache und Pädagogik. Monthly. National Deutschamerikanisches Lehrerseminar, Milwaukee, Wis. Highly recommended. $\$ 1.50$ a year.

Zeitschrift für den deutschen Unterricht. Monthly. Leipzig: B. G. Teubner. $\$ 5.00$.

School Review. Chicago: University of Chicago Press. Has many articles of interest to the teacher of German. $\$ 1.50$.

Modern Language Teaching. London, England. Official organ of the Modern Language Association of England.

Die neueren Sprachen. Marburg. 
Modern Language Notes. Baltimore: Johns Hopkins Press. Contains reviews and lists of recent books. Recommended. Eight numbers a year. $\$ 2.00$.

Breymann-Steinmüller: Neusprachliche Reform-literatur. Published once in about every four years. Contains an exhanstive bibliography and articles on the latest ideas and movements in modern language teaching. Four volumes have so far appeared. Leipzig: A. Deichert.

\section{LARGEly Literary AND CRITICAL}

Literaturblatt für Germanische und Romanische Philologie. Monthly. Leipzig: Riesland. Valuable criticisms and reviews. Bibliography of recent books. $\$ 4.00$.

Germanisch-Romanische Monatsschrift. Heidelberg. Valuable articles and lists of recent books.

Archiv für das Studium der neueren Sprachen und Literatur. Quarterly. Braunschweig: Westermann. \$5.00.

Zeitschrift für deutsches Altertum. Quarterly. Berlin: Weidemannische Buchhandlung. $\$ 6.50$.

Modern Language Review. Cambridge [England]: University Press.

Euphorion. Quarterly. Vienna: Fromme. 5 marks a number.

Die Deutsche Rundschau. Berlin: Geb. Paetel. $\$ 10.00$ a year.

Die Neue Rundschau. Gross-Lichterfelde: Paul Zollmann. \$9.00 a year.

Das literarische Echo. Berlin: Fleischel \& Company. \$5.00.

\section{B. FOR STUDENTS}

A us Nah und Fern. Chicago: F. W. Parker School Press. 50 cents a year, club rate 40 cents.

Der gute Kamerad (for boys) and Das Kränzchen (for girls). Stuttgart und Berlin: Union Deutsche Verlagsanstalt. \$2.00 each per year.

\section{FOR STUDENT USE IN THE LIBRARY}

Die Woche. Berlin. Popular; illustrated. $\$ 2.00$ per year.

Ueber Land und Meer. Stuttgart: Deutsche Verlags Anstalt. \$5.50 a year.

Die Gartenlaube. Leipzig: E. Keils Nf. August Scherb. Long one of the most popular of German family papers. $\$ 4.00$ a year.

Leipziger Illustrierte Zeitung. Recommended. $\$ 9.00-\$ 10.00$ a year.

\section{AMERICAN GERMAN DAILY PAPERS}

Die New Yorker Staatszeitung. New York.

Illinois Staatszeitung. Chicago.

Volkszeitung. St. Paul.

Herald. Minneapolis. 


\section{THE LIBRARY}

Even a small library, properly equipped with periodicals and books for reference and outside reading, can be used to stimulate interest and to promote scholarship. The selection of books, especially if only a small amount of money is available, is very difficult; but the time and energy the teacher expends upon this will repay itself many times, provided always that the teacher sees to it that the books are used. Books, no matter how good they may be, are worse than useless if they are merely given a place upon the library shelves.

The right kind of teacher will not need to drive his students to the library. If he really loves his work and has that kind of enthusiasm that stimulates others, his students will want to read in the library and at home. If, however, he desires the student to secure the most benefit for time and effort expended, the teacher must also direct the reading of his students. He should himself know what a book contains, and whether it is the right kind of book for a particular student and serves the purpose for which the student is to read it. Do not let a student have a book that is beyond him in difficulty of language or in thought content. Do not make outside reading a task; make it a pleasure.

The library should contain one or more periodicals of a kind and character that will benefit the greatest number. To order a magazine that is of interest and benefit to the teacher only is selfish, if not dishonest to the best interests of the school and to the community that pays the bills. Choice of illustrated periodicals is strongly recommended, but the illustrations should be worth while, dealing for the most part with Land und Leute and with current events. For a suggestive list of such journals see the list of journals for student use on page 33 .

The library should contain one of the larger dictionaries, not so much that the student may use it for ordinary study purposes as that he may have a source of information when his own smaller dictionary or the vocabulary in his text-book does not suffice.

Reference books should consist of a representative number 
of such books as are listed under Land und Leute, page 18, History, page 30, and Literature, pages 27 and 28 .

Books of a strictly literary nature should be selected with the purpose of supplying first the real needs of the course of study, and not until that has been done should books be considered that will also serve the community in which the school is situated.

Below is a suggestive list of standard works. The range of difficulty and the fitness of any one book for the class and the community must be left to the judgment of the teacher. It may seem to some that the works of the classic authors and also a list of more modern writers should have been included. But this also will be left to the teacher who takes a proper interest in his own reading. Above all things do not buy trashy books. That is an unpardonable waste of money and only harms the school. The list below contains only books of recognized literary merit and most of them can be bought for a very small sum of money.

\section{BOOKS FOR THE LIBRARY}

\section{A. COLLECTIONS OF STANDARD WORKS}

The collected works of any single author will rarely be desirable unless the school library is also the community library or there is otherwise a demand for such readings. Bibliographies containing lists of such works can be found in the catalogs of publishers and importers of German books.

Kürschners Deutsche National Literatur. Leipzig. This is a large and representative collection of the best writings in German literature, but no modern authors are represented. Separate volumes can be secured. Inexpensive. For the list write to any importer of German books.

Reclames Universal-Bibliothek. Leipzig. This is a very serviceable collection of standard works. Separate volumes can be bought for from 10 to 40 cents, paper binding. For the library it is best to buy the board binding. This increases the cost by very little. For list write to any importer of German books.

\section{B. COLLECTIONS OF SHORT STORIES}

For Young Students, first year and first half of second year.

Wenckebach, Aus meiner Welt. New York: Henry Holt \& Company. Guerber, Märchen und Erzählungen. 2 vols. Boston: D. C. Heath \& Company.

Bcrnhardt, Novelleten Bibliothek. 2 vols. Boston: D. C. Heath \& Company. More difficult than the two preceding. 
For MORE Advanced STudents, third and fourth years.

Heyse-Kurz Novellenschatz. Eighty-six stories in twenty-four volumes. Berlin: Globus Verlag. The list of stories can be secured from any importer of German books. Each volume can be bought separately. Inexpensive.

Heyse-Laistner Neuer Novellenschatz. 24 vols. Berlin: Globus Verlag. A collection like the preceding. Each volume can be bought separately. Inexpensive. Get the list from any importer of German books.

\section{SEPARATE WORKS}

Many of the works listed in the following may be found in one of the two collections previously listed under B on page 35 . A large number of them have also been published as textbooks by American firms. The majority are inexpensive.

Those marked * are elementary. Those marked $\dagger$ are either difficult or long. The others are best adapted for students in the last half of the second year and in the third year.

STORIES

Anderson, *Bilderbuch ohne Bilder

Arnim, $\dagger$ Der tolle Invalide

Arnold, Fritz auf Ferien -

Auerbach, $\dagger$ Auf der Höhe.

- †Barfüssele

$\longrightarrow$ Brigitta

—Diethelm von Buchenhag

$\lceil$ - $†$ Edelweiss

- Joseph im Schnee

Anzengruber, $\dagger$ Der Schandfleck

†Der Sternsteinhof

Baumbach, Das Habichtsfräulein.

- Märchen

* Nicotiana

- Die Nonna

Der Schwiegersohn

*Sommermärchen

Brentano, Geschichte vom braven Kasperl und dem schönen Annerl - Das Märchen von Gockel; Hinkel und Gackeleia

Blüthgen, Das Peterle von Nïrnberg

Chamisso, $\dagger$ Peter Schlemihl.

Dahn, $\dagger$ Bissula

$-\dagger$ Felicitas

†Gelimer

pany.)

†Kampf um Rom. (Can be had abridged. Heath \& Com- 


\section{STORIES-(continued)}

Droste-Hülshoff, Die Judenbuche

Ebers, †Eine Frage

- †Homo Sum

Ebner-Eschenbach, Freiherren von Gemperlein

Das Gemeindekind

Lotti die Uhrmacherin

Die Unverstandene auf dem Dorfe

Eckstein, Der Besuch im Karzer

$\dagger$ Die Claudier

Eichendorff, Aus dem Leben eines Taugenichts

Fontane, Grete Minde

† Vor dem Sturm

Fouqué, †Undine

Frennsen, †Jörn Uhl

†Peter Moors Fahrt nach Südwest

Freytag, $\dagger$ Ingo. (Can be had abridged. The Macmillan Company.)

- $\nmid$ Rittmeister von Altrosen

†Soll und Haben. (Can be had abridged. Ginn \& Company,

or Heath \& Company.)

Macmillan Company.)

Frommel, Eingeschneit

Mit Ränzel und Wanderstab

Ganghofer, †Edelweisskönig

+ Der Herrgottschnitzer von A mergau

†Der Laufende Berg

†Tarantella

Grillparzer, Der arme Spielmann

Grimm, *Kinder und Hausmärchen. (Should be obtained in the simplified text.)

Halm, Marzipan-Lise

Hauff, Das kalte Herz

- Die Karavane

tLichtenstein.

(Can be had in an abridged text. D. C. Heath \& Company, or Henry Holt \& Company.)

- Der Mann im Monde

Hauff, Sheik von Allessandrien

- Das Wirtshaus im Spessart

Der Zwerg Nase

Heyse, Anfang und Ende

- Die Blinden

- Die Hochzeit auf Capri

L'Arrabbiata

- Das Mädchen von Treppi

- Niels mit der offenen Hand

$\dagger$ Stiftsdame

Hillern, †Geier-Wally 
STORIES-(continued)

Höher als die Kirche

$\dagger$ Und sie kommt doch

Hoffmann, †Das Fräulein von Scuderi

— $†$ Meister Johannes Wacht †Meister Martin der Küfner

Jensen, Die braune Erica

Keller, Dietegen

- Die drei gerechten Kammacher

- Das Fühnlein der sieben Aufrechten

- Kleider machen Leute

- Legenden.

Romeo und Julia auf dem Dorfe

Kinkel, Otto der Schütz

Kleist, Das Erdbeben in Chile

— $†$ Michael Kohlhaas

Die Verlobung in St. Domingo

Kurz, †Weihnachtsfund

Lilienkron, Anno I87o

Ludwig, $\nmid$ Heiterethe $i$

†Zwischen Himmel und Erde

Marlitt, †Goldelse (For girls)

- †Heideprinzesschen (For girls)

†Reichsgräfin Gisela (For girls)

Meyer, Gustav Adolfs Page

- Der Heilige

† Jiirg Jenatsch

Der Schuss von der Kanzel

Möricke; Das Hutzelmännlein

- † Mozart auf der Reise nach Prag

Raabe, Else von der Tanne

- Eulenpfingsten

Die schwarze Galeere.

Riehl, Burg Neideck

- Der Fluch der Schönheit

- Meister Martin Hildebrand

- Die vierzehn Nothelfer

Das Spielmannskind

Rosegger, $\dagger$ Försterbuben

- Holzknechthaus

- Der Lex von Gutenhag

$\uparrow$ - $†$ Shriften des Waldschulmeisters

Scheffel, $\dagger$ Ekkehard

- $†$ Der Trompeter von Säkkingen. (In verse)

Schiller, Der Geisterseher

Schubin, †Wenn's nur schon Winter wär'.

Schücking, *Die drei Freier

Seidel, Leberecht Hiihnchen 


\section{STORIES-(continued)}

Spielhagen, $\dagger$ Allzeit voran

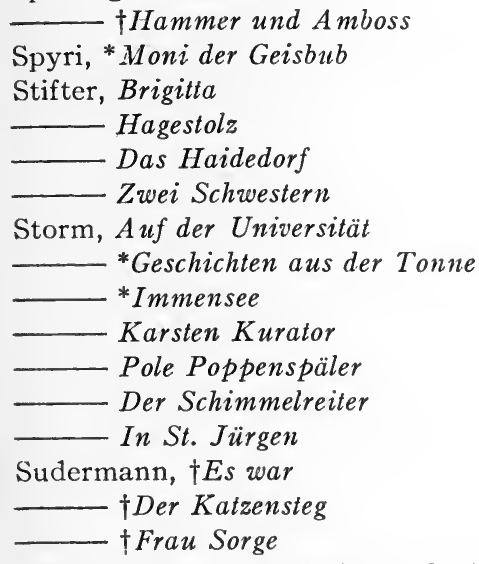

Sylva, Carmen, Aus meinem Königreich

Tieck, Der blonde Eckbert

$-\dagger$ Der Gelehrte

$\dagger$ Die Gemälde

Die schöne Magalone

$\lceil$ Des Lebens Ueberfluss

Viebig, $†$ Das tägliche Brot

$\lceil$ -

Wildenbruch, Das edle Blut

- Der Letzte

\section{Kindertränen}

Zschokke, $\dagger$ Das Abenteuer der Neujahrsnacht

— $†$ Der tote Gast

- Der zerbrochene Krug

- Das Wirtshaus zu Cransac

Plays

See also the list under Plays for Acting, page 22.

Anzengruber, $\dagger$ Pfarrer von Kirchfeld

$$
\dagger \text { Das Vierte Gebot }
$$

Freytag, $\nmid$ Die Journalisten

Fulda, Der Dummkopf

$\dagger$ Der Talismann

Sieben Einakter

Grillparzer, $\dagger$ Die Ahnfrau

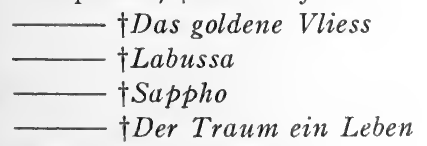

Gutzkow, Uriel Acosta 
Plays-(continued)

- Zopf und Schwert

Halm, Sokn der Wildnis

Griseldis

Hauptmann, $\dagger$ Armer Heinrich

- †Einsame Menschen

$\dagger$ Elga

$\dagger$ Das Friedensfest

- †Hanneles Himmelfahrt

- + Die Weber (Not the dialect version)

$\nmid$ Die versunkene Glocke

Hebbel, $\dagger$ A gnes Bernauer

- †Gyges und sein Ring

- Herodes und Mariamne

—

$\dagger$ Die Nibelungen

Kleist, $\dagger$ Das Kätchen von Heilbronn

Hombur

Laube, Karlschïler

Ludwig, $\dagger$ Erbforster

Sudermann, $\dagger$ Es Lebe das Leben

- †Johannes

† Johannesfeuer

$\longrightarrow$ †eimat

Evigmännliche)

$\dagger$ Morituri (Three one-act plays: Fritzchen, Teja, Das

Poetry

Arnim-Brentano, Des Knaben Wunderhorn

Baumbach, Frau Holde

Krug und Tintenfass

Eichendorff, Gedichte

Freiligrath, Gedichte

Fulda, Gedichte

Heine, Buch der Lieder. Romanzero

Hoffmann von Fallersleben, Gedichte

Körner, Leier und Schwert

Rückert, Gedichte

Schenkendorf, Gedichte

Uhland, Balladen und Romanzen

Nearly all the above can be had in the Reelame Universal-Bibliothek for a small sum each. A number of text-books offer good collections.

Buchheim, Balladen und Romanzen (Golden Treasury Series. The Macmillan Company.)

Company.)

Deutsche Lyrik (Golden Treasury Series. The Macmillan

Burkhard, German Poems for Memorizing. Henry Holt \& Company. 
POETRY-(continued)

Hatfield, Lyrics and Ballads. D. C. Heath \& Company.

Klenze, Deutsche Gedichte. Henry Holt \& Company.

Mueller, Deutsche Gedichte. Ginn \& Company.

Schlenker-Juergensen, Deutsche Gedichte. Minneapolis: Northwestern School Supply Company.

\section{RELIABLE IMPORTERS}

G. E. Stechert \& Company, 155 W. 25th St., New York. (Books, maps and all illustrative materials, charts, cards, etc.)

W. R. Jenkins Company, 851 6th Ave., New York. (Books, illustrative material.)

McClurg \& Company, Chicago. (Books.)

Lemcke \& Buechner, 812 Broadway, New York. (Books.)

A. J. Nystrom \& Company, 623 S. Wabash Ave., Chicago. (Maps, charts, illustrative material.)

Ritter \& Flebbs, 120 Boylston St., Boston. (Illustrative material.) 


\section{FOURTEEN DAY USE}

\section{RETURN TO DESK FROM WHICH BORROWED}

This book is due on the last date stamped below, or on the date to which renewed.

Renewed books are subject to immediate recall.

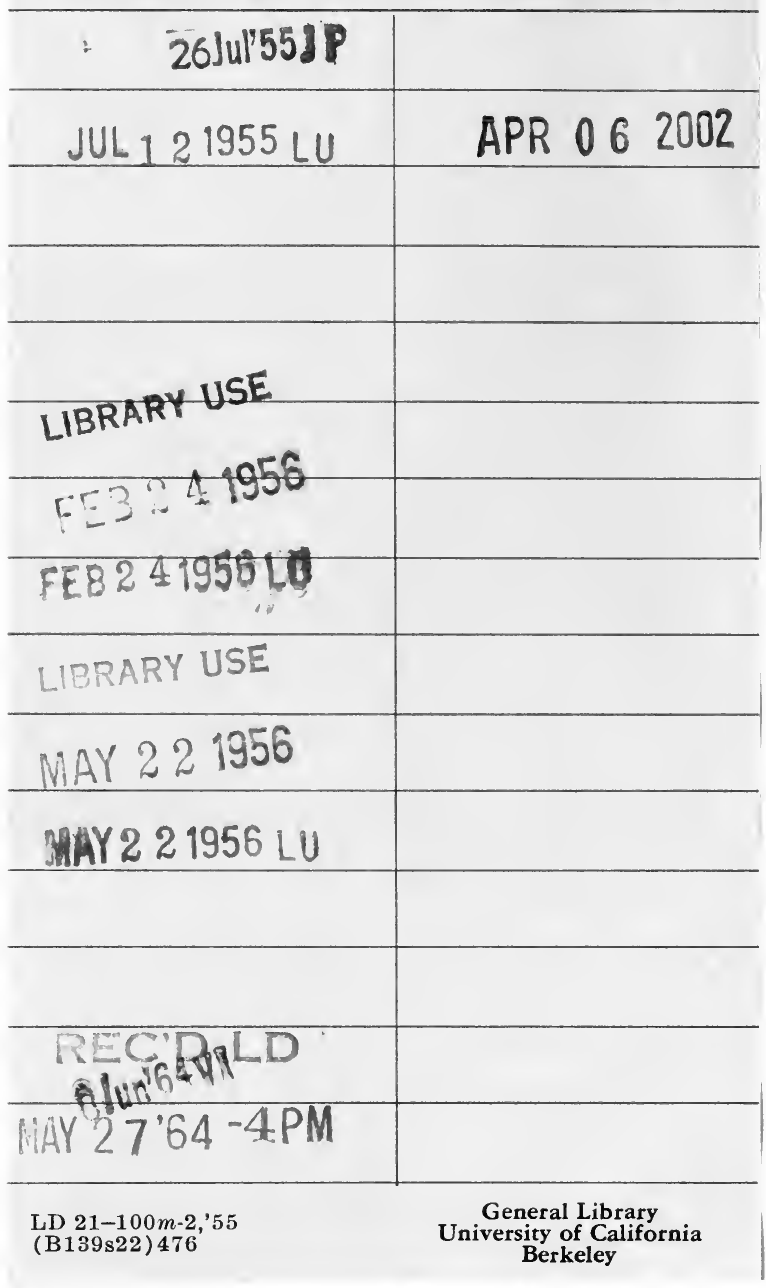

$\mathrm{FB} 4 \mathrm{~A}$ 


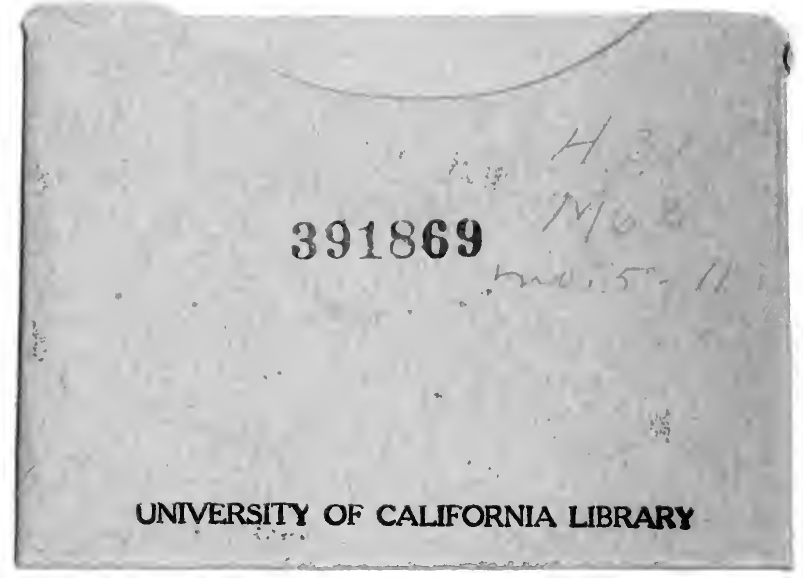

$\therefore$

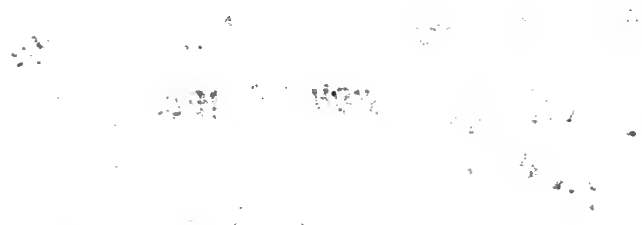

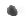


